tions are seldom encountered even with the most energetic infusions. Also in a series of 84 adults to be published shortly ${ }^{1}$ the patients commonly had large fluid deficits and several litres of fluid had to be infused before urine flow became established. As demonstrated in the case report of Dr. Savege and his colleagues, an increased urine flow is an important factor in salicylate clearance. In some patients, therefore, a rapid infusion rate is mandatory.

Drs. Morgan and Polak also claim that their regimen is free from important complications, but this is perhaps hardly justified, as six of their ten patients developed capillary $p \mathrm{H}$ values in excess of $7 \cdot 5$, and although all the serum potassium levels were normal at the outset eight developed significant hypokalaemia with a potentially dangerous level in five. As these changes occurred rapidly, it seems likely that considerable acid-base changes with associated electrolyte shifts were taking place. These findings are similar to those encountered with the early regimens of forced alkaline diuresis described by Cumming and his colleagues in $1964 .^{2}$

Treatment with bicarbonate and acetazolamide, therefore, still requires very careful laboratory control and in its present form, is less safe than the newer modifications of the Cumming's regimen referred to in your leading article (January 4, p. 3).-I am, etc.,

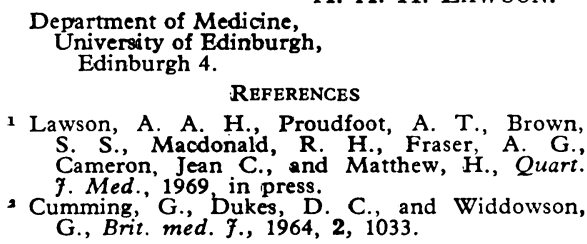

1 Lawson, A. A. H., Proudfoot, A. T., Brown, S. S., Macdonald, R. H., Fraser, A. G., f. Med., 1969 in press.

Cumming, G., Dukes, D. C., and Widdowson G., Brit. med. f., 1964, 2, 1033 .

\section{Recirculating Pump and the Rupture of Ultraflow Twin Coils}

SIR,-The twin-coil dialyser with fibreglass supports remained basically unchanged for a decade after its introduction. ${ }^{2}$ The only major improvement in its performance over that period was achieved by sealing it more efficiently in its case with a pneumatic cuff and substituting a faster recirculating motor. ${ }^{2}$ This combination imposed a considerable shearing stress on the coil, which was only partly prevented by an improved upper support, ${ }^{3}$ but no harm ensued. The membrane was encased in a double-sewn layer of fibreglas mesh so that individual winds of the coil could move on one another without damage to the membrane.

During 1968 fibreglass coils were superseded by the Ultraflow range incorporating Hoeltzenbein's non-woven plastic mesh. These give a higher clearance and ultrafiltration at a lower priming volume and residual blood volume than fibreglass coils of the same area. ${ }^{4-6}$ Following the changeover several centres, including our own, experienced a disturbing rise in the proportion of coils which ruptured early in dialysis with a major blood leak into the dialysate. In our case the leakage rate rose from less than $1 \%$ with fibreglass coils to a peak of $5 \%$ with early production batches of the Ultraflow. We were advised to soak the coil for 15 minutes before priming, and to prime at slow speed (setting of 10 on the Sarns pump), and have observed these precautions since. There was no striking reduction in the leakage rate, and we think that these time-consuming precautions should be studied in a controlled trial. We did, however, notice a relationship between the recirculating pump employed and the incidence of rupture, and this problem was examined under controlled conditions.

Of four identical outlets of a multiple patient system, three were fitted with standard Travenol pumps producing about $20 \mathrm{l} . / \mathrm{min}$., and one with a fast pump yielding about $40 \mathrm{1} / \mathrm{min}$. All coils were sealed in their cans with a full width cuff at $200 \mathrm{~mm}$. Hg. During 58 dialysis days there were nine leaks in 67 coils on the fast pump and two leaks in 176 coils on the standard pumps; the difference is significant $(0.02<\mathrm{P}<0.03)$.

We conclude that the Ultraflow coil is more easily damaged by shearing stress than its predecessor, presumably because a single layer of mesh separates successive layers of membrane ; any distortion of the coil must result in friction on the membrane. The value of a very fast recirculation rate has not been established with the Ultraflow, and any small advantage it may give in clearance is certainly outweighed by the risk of coil rupture. We recommend a return to the standard pump for the time being.-We are, etc.,

William Crossley. Peter J. B. Tilley. DAVID N. S. KERR.

Department of Medicine,
Wellcome Research Laboratories. Wellcome Research Laboratories,
University of Newcastle upon Tyne.

\section{REFERENCES} Kolff, W. J., and Watschinger, B., f. Lab. clin.

Elliott, W., Horn, D. B., Kerr, D. N. S., and Pearson, D. T., Lancet, 1961, 1, 248.
Shaldon, S., Silva, H., and Rosen, S. M., Brit. med. F., 1964, 2, 411 . $R$, and Michielson P., in Proceedings of the European Dialysis and Transplant Assoc., edited by D. N. S. Kerr, Transplant Assoc., edited by D. N. S. Kerr, Excerpia Medica International Congress 'Series Excerpta Medica Internation.
No. 155, 1968. Amsterdam.

Pearson, M. R., et al., in Proceedings of the European Dialysis and Transplant Assoc., edited Elliott, 1967, 4, 386. Excerpia Medica International Congress Series No. 155, 1968 Amsterdam.

Easterling, R. E., Haig, O. G., and Greene, J. A.,
Trans. Amer. Soc. artif. intern. Org., 1968, 14, 114.

\section{Epidemic Influenza and General Hospitals}

SIR,--In your leading article on epidemic influenza and general hospitals (14 December, p. 655 ) you state "perhaps $95 \%$ of patients with epidemic influenza withstand their (infections without undue inconvenience" (my italics). Between 15 January 1953 and 5 May 1953 the Army Chest Centre (Connaught Hospital, Bramshott) was asked to deal with the overflow of cases of viral respiratory tract infection involving a predominantly young military community. In all, 500 cases were admitted and every case had a radiograph of the chest on arrival in hospital. The incidence of pulmonary opacities was most revealing - at least $13 \%$ of all cases-but in certain categories the incidence was as much as one in five. All such cases had clearance chest radiographs so as to estimate the time taken for complete resolution. ${ }^{1}$ It is felt that in many cases without chest radiography a significant number of pulmonary opacities will be missed and cases returned to work before they are really fit to do so, with the inevitable "relapse." This stresses the need for facilities for domiciliary chest radiography. ${ }^{3}$

A review of 355 consecutive cases of viral respiratory tract infection admitted to a British military hospital in Belgium between 24 November 1945 and 14 January 1946 indicated that considerably less than $95 \%$ of patients had an easy passage. ${ }^{4}$ - I am, etc.,

Edinburgh 12.

JOHN MACKAY-Dick. REFERENCES

1 Mackay-Dick, J., Brit. med. 7., 1955, 1, 1279. f. roy. Army Med. Cps, 1955, 101, 292.' Mackay-Dick, J., Brit. med. Ұ., 1956, 1, 1239. Mackay-Dick, J., Brit. roy. Army Med. Cps. 1962,
108, 202.

\section{Lithium and Foetal Abnormalities}

SIR,-The question was recently raised (11 January, p. 102) whether there is risk of teratogenic effects from lithium treatment. We agree entirely with the information given and the views expressed in the answer. A number of systematic studies on rats and rabbits are now under way; some are not yet finished, others are finished but not published. The experiments have until now been clearly negative. No malformations have been observed in the young of lithium-treated mothers.

Furthermore, a Scandinavian register of "lithium babies" was founded about one year ago. At present it contains records of 20 children born of mothers who had been treated with lithium. In four cases lithium was given within the first trimester, in 16 cases throughout the pregnancy. None of the children had malformations. It would be desirable to extend the series with cases from outside Scandinavia. Any relevant information may be sent to us.-We are, etc.,

\section{Mogens Schou. AMdi AMdisen. \\ Psychopharmacology Research Unit, A240 University Psychiatric Institute, \\ Synacthen Depot Used in General Practice}

SIR,-The papers ${ }^{1-3}$ and the letter ${ }^{4}$ that you have already published on Synacthen depot have demonstrated its longer duration of action and its tolerability by patients sensitive to natural A.C.T.H., but they have given rather little information on its clinical usefulness and none under the conditions of general practice. We have recorded details of the first 60 patients treated in a general practice, and the results seem interesting enough to report.

One patient was of particular interest and his case merits special comment. A man of 45 years of age with rheumatoid arthritis of three and a half years' duration was previously being treated with indomethacin $25 \mathrm{mg}$. three times a day and aspirin $3.6 \mathrm{~g}$. daily with only moderate control, since he was unable to work at his job of plasterer's labourer for the greater part of this time. He was started on injections of Synacthen depot $1 \mathrm{mg}$. daily for three injections, and the interval between injections was progressively extended from two to seven days over the next month. The dose was then reduced to $0.5 \mathrm{mg}$. weekly, and he has continued on this for over two months. 